\title{
The Relationship between the Anti-Sperm Antibodies and Immunologic Infertility
}

\author{
Ashrafizadeh $\mathrm{M}^{1 *}$ and Ahmadi Z² \\ ${ }^{1}$ Department of basic science, veterinary medicine faculty, Tabriz University, Tabriz, \\ Iran
}

${ }^{2}$ Department of basic science, veterinary medicine faculty, Shushtar University, Khuzestan, Iran

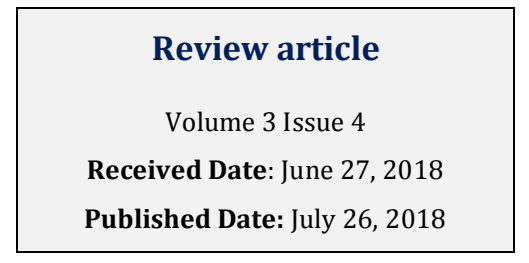

*Corresponding author: Milad Ashrafizadeh, Department of basic science, veterinary medicine faculty, Tabriz university, Tabriz, Iran, Tel: +989032360639; Email: dvm.milad73@yahoo.com

\begin{abstract}
Infertility is an outbreak phenomenon in the world and the outbreak of it is increasing. The anti-sperm antibodies (ASA) are one of the causes of infertility and the resultant infertility of them is called immunologic infertility. The ASA are present at the normal level in the circulating blood, but the higher level of them is harmful for the sperm cells and leads to the lower fertility potential. The blood-testis barrier (BTB) is a strong structure which protects sperm cells from the adverse effects of ASA and any change in this barrier interrupts the fertilization and fertility. In general, any factor that causes the contact between the ASA and sperm cells, leads to the lower fertility and even infertility. In this review, we investigated the role of the BTB in protection of sperm cells and the negative effects of ASA on the spermatozoa in preand post-fertilization steps.
\end{abstract}

Keywords: Infertility; Immunologic; Anti-Sperm Antibodies; Blood-Testis Barrier

Abbreviations: CM: Cervical Mucus; BTB: BloodTestis Barrier; ASA: Anti-Sperm Antibodies; IUI: IntraUterine Insemination; MAR: Mixed agglutination reaction; SIT: sperm immobilization test; TAT: Tray Agglutination Test; ELISA: enzyme-linked immunosorbent assay.

\section{Introduction}

The outbreak of infertility is growing in the world. It has been shown that the male factors such as sperm quantity and quality are responsible for 30-50 percent cases of infertility [1]. It has been reported that low count or quality of sperm is the cause of the infertility in almost
20 percent of couples [1]. Infertility is the lack of pregnancy after 12 months of regular intercourse without protection and is because of the disturbance in the reproduction ability in one of the partners. Subfertility is almost the equivalent of the infertility. It is a form of declined fertility. The constant form of infertility is called sterility [2]. The parameters such as sperm quality and quantity, sperm motility, sperm DNA integrity and stress oxidative designate the fertility potential.

The etiology of infertility can be divided into six parts: 1. Testicular disorders

2. Hypothalamic-hypophyseal tract 


\section{International Journal of Biochemistry \& Physiology}

\section{Seminal tract disorders}

4. Immunologic conditions

5. Psychosomatic disorders

6. Using testosterone, anabolic steroids, and antifungal medicines such as ketoconazole [1].

One of the causes of infertility is the immunologic (autoimmune) reactions against sperm cells. It has been shown that there is Anti-Sperm Antibodies (ASA) in 8$21 \%$ of infertile men, whereas there are ASA in the 1.2$19 \%$ of fertile men, so this statement asserts that all ASA are not responsible for the infertility [3-5]. ASA have adverse effects on the pre- and post-fertilization incidents. The ASA exert effects on the motility, interaction of gamete, early embryonic development, implantation process and fetal development [6-9]. Some authors state that the ASA exert their effects by affecting the motility of sperm and agglutination. Other authors say that ASA have no influence on the fertilization [10-13]. The ASA not only affect the sperm, but also affect the antibodies in the cervical mucus interfere with the motility of sperm and gamete interaction [14]. In this review, we will investigate the effects of ASA and the antibodies in the cervical mucus on the fertility potential and the tests for recognition of those antibodies.

\section{ASA and Blood-Testis Barrier}

Blood testis barrier (BTB) is a basic and important structure of the seminiferous epithelium that is created by sertoli cells. It divides the seminiferous epithelium into two separate parts, namely albuminal and basal parts. The tight junctions, desmosomes, gap junctions and basal ectoplasmic specializations reinforce this barrier $[15,16]$. The BTB has separate domains and that makes it peerless, because in contrast to other blood-tissue barriers, its junctions function together. The unique organization of BTB junctions provides a rigid harmony and that is why the BTB is the strictest blood-tissue barrier. The postmeiotic germ cells are supported from the immune system by BTB. Furthermore, it provides a safe condition for preleptotene spermatocytes to develop [17-19]. The spermatogonia and early spermatocytes are not protected by BTB and the support of them relies on immunosuppressive agents. Trauma, vasectomy, orchitis and/orepididymitis, varicocele and spinal cord injury are factors that can create damages in the BTB [20-25]. Finally, this interruption allows the anti-sperm antibodies to be found on the surface of sperm. The interesting hint is that the ASA are polyclonal and this feature makes it possible to attach to the multiple antigens of sperm. Also, as we mentioned in the introduction, the attendance of those antibodies does not always result in the impairment in the function of sperm (Figure 1).

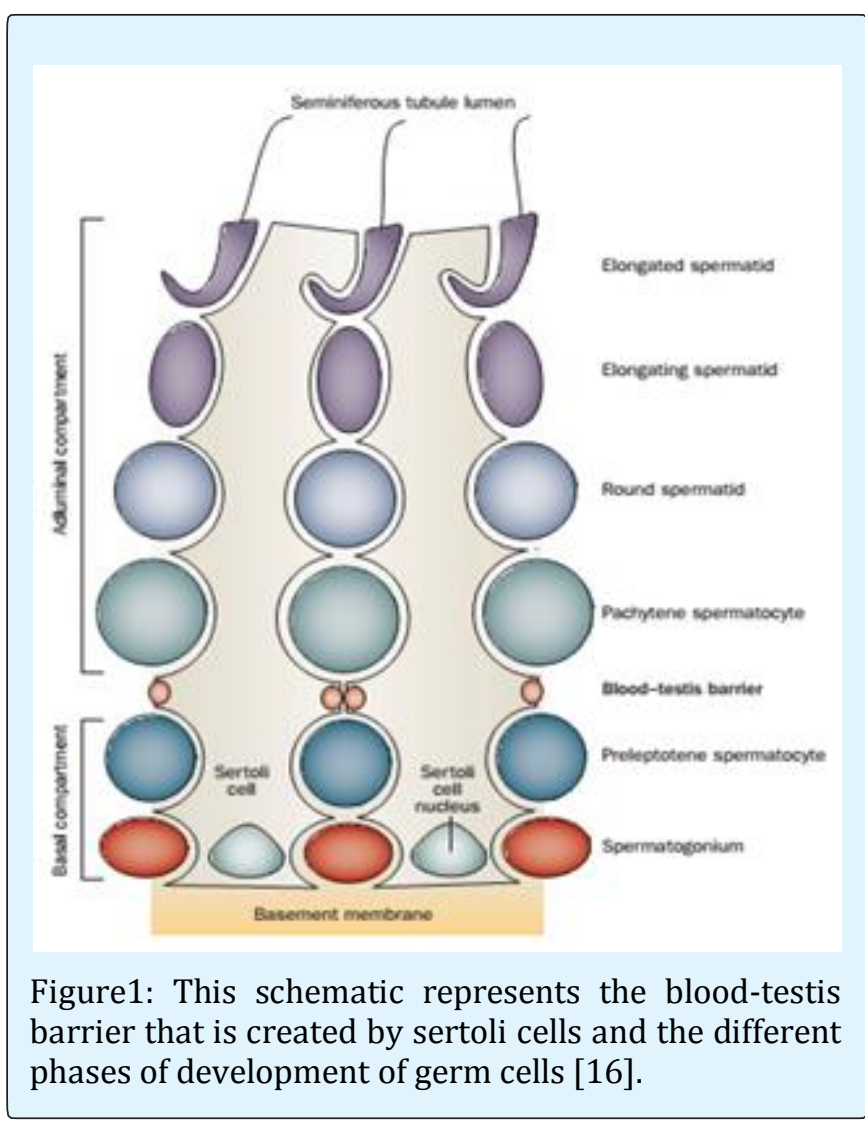

\section{ASA and Adverse Effects on the Sperm Cells}

It has been shown that the ASA in the blood negatively affect the pregnancy. The investigation of ASA in the secretions of genital tract, particularly the secretions of cervical mucus is necessary. The immunoglobulins such as IgA and IgG that are produced by cervical mucus, act against the antigens of sperm [26]. It has been reported that the cervical mucus's sperms have more potential for immobilizing the sperm than the antibodies of serum $[27,28]$. The level of antibodies in the seminal plasma of infertile men relies on the level of those antibodies in the serum. There are differences in the ASA of the sperm surface in males, for instance the various classes of ASA, different locations of antigens for ASA and the various activities of ASA $[29,30]$.

It has been observed that in males who are immunologically infertile, the asthenozoospermia occurs. Furthermore, the ASA which affect the motility, have been detected [30]. The impairment migration of sperm cells 


\section{International Journal of Biochemistry \& Physiology}

through CM is created by sperm immobilizing antibodies which are secreted from CM. The occurrence of pregnancy is low in the persons with high ASA and the possibility of fecundity is also low with intra-uterine insemination (IUI) in these patients $[31,32]$. The intervention of ASA is not only limited by the sperm migration from $\mathrm{CM}$, but also they block the fertilization (occlusion of zona pellucida) [33-36]. Besides, the survival of sperm cells in the peritoneal fluid is lower in the persons with high ASA than normal persons. So, this finding shows that the transporting of sperm from uterine cavity through fallopian tubes to the peritoneal cavity is affected by ASA. Furthermore, the concentration of ASA in the serum and peritoneal fluid is same and the level of complement in the peritoneal fluid is enough for the sperm immobilization [37]. The agglutination of sperm can create troublesome problems in the motility and cervical penetration and the level of agglutination is more in the persons with high ASA $[38,39]$. Also, the activation of complement-mediated cellularly is of the sperm can be started by ASA [40]. In addition, the cytotoxic antibodies negatively affect the motility and low survival of sperm is the result of these antibodies [41]. The ASA decrement the capacitation by preventing the liquidity of spermatozoa plasma membranes [42]. The survival of embryo is affected by the post-fertilization antibodies. Spermderived CS- 1 is a protein which is targeted by ASA and has a role in creating post-fertilization defects of embryo [43]. The triumph in conception is affected by ASA and ASA inwikt in the serum of female and ejaculated sperm might produce abortion in the first trimester [44]. In general, aside from the post-fertilization effects of ASA, the prefertilization effects of these antibodies include agglutination of sperm, sperm cytotoxicity, poor cervical penetration, acrosome reaction and poor oocyte binding $[45,46]$.

\section{ASA and Recognition Tests}

There are direct (recognition of ASA on the sperm surface) and indirect (recognition of ASA in the female genital tract or partner serum) tests for detecting ASA [47]. Direct immune bead test is one of the direct tests which is used for identifying the sperm-attached antigens. In this procedure, the polyacrylamide beads covered with the antihuman immunoglobulin antibodies that are against the ? ? and chains. Then, these antibodies attach to the antigens that are located on the surface of sperm. Mixed agglutination reaction (MAR) test is another direct test for detecting the antigens on the surface of sperm. An attaching antibody (anti-IgG or anti-IgA) is applied to create contact between the antibody-coated beads and the unwashed spermatozoa which carry the IgG or IgA in their surface [48]. The indirect tests such as sperm immobilization test (SIT), tray agglutination test (TAT), gel agglutination test (GAT), enzyme-linked immunosorbent assay (ELISA), flow cytometry and radioimmunoassay tests are used to follow ASA in the seminal fluid, sperm extract, cervical mucus and/or sera. Each of these tests has benefits and pitfalls in terms of sensitivity, specificity, generating quantitative information, and cost and the required skills [6].

\section{Conclusion}

According to the spread of infertility and due to the normal parameters in the sperm analysis test of individuals with unexplained infertility, the ASA are one of the possible reasons for creating that condition. So, the clinicians should pay attention to the ASA. Also, men must avoid from the conditions or situations that injure the BTB and creating a contact between ASA and sperm cells. The clinicians should consider the cost of the tests for detecting those antibodies and still there is a far way for overcoming the ASA and lowering the cost of the tests for identifying ASA.

\section{References}

1. Navdeep Ghuman, Mythili Ramalingam (2018) Male infertility. Obstetrics, Gynaecology and Reproductive Medicine 28(1): 7-24.

2. Zegers-Hochschild F, Adamson GD, Dyer S, Racowsky C, de Mouzon J, et al. (2017) The International Glossary on Infertility and Fertility Care, 2017. Fertil Steril 108(3): 393-406.

3. Krause WK (2009) Sperm functions influenced by immune reactions. Immune Infertility Springer 49-65.

4. Francavilla F, Barbonetti A (2017) Male autoimmune infertility. Immune Infertility, Springer 187-196.

5. Vazquez-Levin $\mathrm{MH}$, Marín-Briggiler $\mathrm{CI}$, Veaute $\mathrm{C}$ (2014) Antisperm antibodies: invaluable tools toward the identification of sperm proteins involved in fertilization. Am J Reprod Immunol 72(2): 206-218.

6. Mazumdar S, Levine AS (1998) Antisperm antibodies: etiology, pathogenesis, diagnosis, and treatment. Fertil Steril 70(5): 799-810. 


\section{International Journal of Biochemistry \& Physiology}

7. Bronson RA (2000) Antisperm antibodies: a critical evaluation and clinical guidelines. J Reprod Immunol 45(2): 159-183.

8. Chiu WW, Chamley LW (2004) Clinical associations and mechanisms of action of antisperm antibodies. Fertil Steril 82(3): 529-535.

9. Cui D, Han G, Shang Y, Liu C, Xia L, et al. (2015) Antisperm antibodies in infertile men and their effect on semen parameters: a systematic review and metaanalysis. Clin Chim Acta 444: 29-36.

10. Tomlinson M, Lewis S, Morroll D, British Fertility Society (2013) Sperm quality and its relationship to natural and assisted conception: British Fertility Society Guidelines for practice. Hum Fertil (Camb) 16(3): 175-193.

11. Pagidas K, Hemmings R, Falcone T, Miron P (1994) The effect of antisperm autoantibodies in male or female partners undergoing in vitro fertilizationembryo transfer. Fertil Steril 62(2): 363-369.

12. Yeh WR, Acosta AA, Seltman HJ, Doncel G (1995) Impact of immunoglobulin isotype and sperm surface location of antisperm antibodies on fertilization in vitro in the human. Fertil Steril 63(6): 1287-1292.

13. Vujisić S, Lepej SZ, Jerković L, Emedi I, Sokolić B (2005) Antisperm antibodies in semen, sera and follicular fluids of infertile patients: relation to reproductive outcome after in vitro fertilization. Am J Reprod Immunol 54(1): 13-20.

14. Marshburn PB, Kutteh WH (1994) The role of antisperm antibodies in infertility. Fertil Steril 61(5): 799-811.

15. Mruk DD, Cheng CY (2004) Sertoli-Sertoli and Sertoligerm cell interactions and their significance in germ cell movement in the seminiferous epithelium during spermatogenesis. Endocr Rev 25(5): 747-806.

16. Cheng CY, Mruk DD (2002) Cell junction dynamics in the testis: Sertoli-germ cell interactions and male contraceptive development. Physiol Rev 82(4): 825874.

17. Russell LD, Ettlin RA, Hikim APS, Clegg ED (1993) Histological and histopathological evaluation of the testis. International journal of andrology 16(1): 8383.
18. Hess RA, Renato de Franca L (2008) Spermatogenesis and cycle of the seminiferous epithelium. Adv Exp Med Biol 636: 1-15.

19. Clermont Y, Perey B (1957) Quantitative study of the cell population of the seminiferous tubules in immature rats. Am J Anat 100(2): 241-267.

20. Iqbal PK, Adeghe AJ, Hughes Y, Samra JS, Obhari MS, et al. (1989) Clinical characteristics of subfertile men with antisperm antibodies. Br J Obstet Gynaecol 96(1): 107-110.

21. Mulhall BP, Fieldhouse S, Clark S, Carter L, Harrison L, et al. (1990) Anti-sperm antibodies in homosexual men: prevalence and correlation with sexual behaviour. Genitourin Med 66(1): 5-7.

22. Awsare NS, Krishnan J, Boustead GB, Hanbury DC, McNicholas TA (2005) Complications of vasectomy. Ann R Coll Surg Engl 87(6): 406.

23. Lekili M, Tekgül S, Ergen A, Taşar C, Hasçelik G (1992) Acute experimental unilateral orchitis in the rabbit and its effect on fertility. Int Urol Nephrol 24(3): 291297.

24. Heidenreich A, Bonfig R, Wilbert DM, Strohmaier WL, Engelmann UH (1994) Risk factors for antisperm antibodies in infertile men. Am J Reprod Immunol 31(2-3): 69-76.

25. Knudson G, Ross L, Stuhldreher D, Houlihan D, Bruns E, et al. (1994) Prevalence of sperm bound antibodies in infertile men with varicocele: the effect of varicocele ligation on antibody levels and semen response. J Urol 151(5): 1260-1262.

26. Menge AC, Medley NE, Mangione CM, Dietrich JW (1982) The incidence and influence of antisperm antibodies in infertile human couples on spermcervical mucus interactions and subsequent fertility. Fertil Steril 38(4): 439-446.

27. Soffer Y, Marcus ZH, Bukovsky I, Caspi E (1976) Immunological factors and post coital test in unexplained infertility. Int J Fertil (2): 89-95.

28. Menge A (1977) The role of the cervix and cervical secretions in immunologic infertility. The uterine cervix in reproduction. Georg Thieme Verlag, Stuttgart, pp: 221. 


\section{International Journal of Biochemistry \& Physiology}

29. Shibahara H, Tsunoda T, Taneichi A, Hirano Y, Ohno A, et al. (2002) Diversity of antisperm antibodies bound to sperm surface in male immunological infertility. Am J Reprod Immunol 47(3): 146-150.

30. Shibahara H, Shiraishi Y, Hirano Y, Suzuki T, Takamizawa S, et al. (2003) Diversity of the inhibitory effects on fertilization by anti-sperm antibodies bound to the surface of ejaculated human sperm. Hum Reprod 18(7): 1469-1473.

31. Koyama K (1979) Effects of antisperm antibodies on sperm migration through cervical mucus. Excerpta Med Int Congr Series 51: 705-708.

32. Kobayashi S, Bessho T, Shigeta M, Koyama K, Isojima S (1990) Correlation between quantitative antibody titers of sperm immobilizing antibodies and pregnancy rates by treatments. Fertil Steril 54(6): 1107-1113.

33. Kamada M, Daitoh T, Hasebe H, Irahara M, Yamano S, et al. (1985) Blocking of human fertilization in vitro by sera with sperm-immobilizing antibodies. Am J Obstet Gynecol 153(3): 328-331.

34. Tsukui S, Noda Y, Fukuda A, Matsumoto H, Tatsumi K, et al. (1988) Blocking effect of sperm immobilizing antibodies on sperm penetration of human zonae pellucidae. J In Vitro Fert Embryo Transf 5(3): 123128.

35. Shigeta M, Koyama K, Burkman LJ, Alexander NJ, Isojima S, et al. (1991) Inhibition of sperm-zona pellucida tight binding by sperm immobilizing antibodies as assessed by the hemizona assay (HZA). Nihon Sanka Fujinka Gakkai Zasshi 43(2): 237-238.

36. Shibahara H, Burkman LJ, Isojima S, Alexander NJ (1993) Effects of sperm-immobilizing antibodies on sperm-zona pellucida tight binding. Fertil Steril 60(3): 533-539.

37. Shibahara H, Shigeta M, Toji H, Koyama K (1995) Sperm immobilizing antibodies interfere with sperm migration from the uterine cavity through the fallopian tubes. Am J Reprod Immunol 34(2): 120124.

38. Clarke GN, Elliott PJ, Smaila C (1985) Detection of sperm antibodies in semen using the immunobead test: a survey of 813 consecutive patients. Am J Reprod Immunol Microbiol 7(3): 118-123.

39. Moulik S, Gopalkrishnan K, Hinduja I, Shahani SK (1989) Presence of sperm antibodies and association with viscosity of semen. Hum Reprod 4(3): 290-291.

40. D'Cruz OJ, Haas GG Jr, Wang BL, DeBault LE (1991) Activation of human complement by IgG antisperm antibody and the demonstration of C3 and C5b-9mediated immune injury to human sperm. J Immunol 146(2): 611-620.

41. Mathur S, Rosenlund C, Carlton M, Caldwell J, Barber $M$, et al. (1988) Studies on sperm survival and motility in the presence of cytotoxic sperm antibodies. Am J Reprod Immunol Microbiol 17(2): 41-47.

42. Nakagawa $K$, Yamano $S$, Kamada $M$, Maegawa $M$, Tokumura A, et al. (2004) Sperm-immobilizing antibodies suppress an increase in the plasma membrane fluidity of human spermatozoa. Fertil Steril 82(3): 1054-1058.

43. Naz RK (1992) Effects of antisperm antibodies on early cleavage of fertilized ova. Biol Reprod 46(1): 130-139.

44. Witkin SS, David SS (1988) Effect of sperm antibodies on pregnancy outcome in a subfertile population. Am J Obstet Gynecol 158(1): 59-62.

45. Shibahara H, Shiraishi Y, Suzuki M (2005) Diagnosis and treatment of immunologically infertile males with antisperm antibodies. Reproductive medicine and biology 4(2): 133-141.

46. Shibahara H, Koriyama J, Shiraishi Y, Hirano Y, Suzuki $M$, et al. (2009) Diagnosis and treatment of immunologically infertile women with spermimmobilizing antibodies in their sera. J Reprod Immunol 83(1-2): 139-144.

47. Shibahara H, Koriyama J (2013) Methods for direct and indirect antisperm antibody testing. Methods Mol Biol 927: 51-60.

48. Ayvaliotis B, Bronson R, Rosenfeld D, Cooper G (1985) Conception rates in couples where autoimmunity to sperm is detected. Fertil Steril 43(5): 739-742. 


\section{International Journal of Biochemistry \& Physiology}

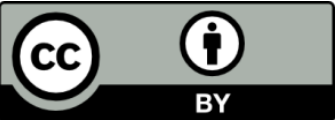

Ashrafizadeh M and Ahmadi Z. The Relationship between the Anti-Sperm Antibodies and Immunologic Infertility. Int J Biochem Physiol 2018, 3(4): 000134. 